\title{
Contribution of the Aquarium of San Sebastián to the conservation of marine turtles Caretta caretta (Linnaeus, 1758) (Testudines: Cheloniidae)
}

\author{
Amalia Martínez de Murguía \& Deborah Leé Herrero \\ Fundación Oceanográfica de Guipúzcoa. \\ biologia@aquariumss.com
}

\begin{abstract}
Since 2000, the Aquarium of San Sebastián (Gipuzkoa, Basque Country) is involved in a sea turtle conservation program that has conducted the tagging and release of 17 specimens of loggerhead Caretta caretta (Linnaeus, 1758). Juveniles and sub adults stranded on the beaches or drifting near the Basque coast are the main life stages found by fishermen and citizens that bring them to our facilities where they are examined and diagnosed. Treatment in quarantine of pulmonary infections, hypothermia and dehydration among others is followed until complete recovery. Ready to swim, they are tagged in the Aquarium of La Rochelle (France) with a French tag series and released with other turtles found in the French Atlantic coast.
\end{abstract}

KEY WORDS: Conservation, loggerhead turtle, recovery, release, tagging.

\section{RESUMEN}

Desde el año 2000, El Aquarium de San Sebastián (Guipúzcoa, País Vasco) participa en un programa de conservación de tortugas marinas que ha realizado el marcaje y liberación de 17 ejemplares de tortuga boba Caretta caretta (Linnaeus, 1758). Los ejemplares recogidos son juveniles y subadultos que aparecen varados en las playas o flotando a la deriva y son rescatados tanto por particulares como por pescadores. En el Aquarium las tortugas se examinan, se realiza un diagnóstico y se les aplica el tratamiento adecuado en cuarentenas hasta su recuperación. Una vez recuperadas y preparadas para su liberación se trasladan a La Rochelle dónde, junto con el resto de tortugas recuperadas en la costa atlántica francesa, se marcan con numeración francesa F y se liberan.

PALABRAS CLAVES: Conservación, marcaje, recuperación, suelta, tortuga boba.

\section{LABURPENA}

2000. urtetik aurrera, Donostiako aquariumak (Gipuzkoa, Euskal Herria) itsas dortoken errekuperazio programa batean hartzen du parte. Ordutik hona, 17 benetazko kareta Caretta caretta (Linneaus, 1758) ale markatu eta askatu ditu. Jaso ohi diren dortokak, dortoka gazteak dira heldutasun garaira iritsi ez direnak. Orokorrean gure hondartzetara osasun egoera kaskarrean iritsitakoak edo eta gure kostaldeko uretan jitoan dabiltzala topaturikoak dira. Guztiak, partikularrek edo arrantzaleek erreskatatutako itsas dortokak dira. Aquariumera iristen direnean, duten osasun egoeraren diagnostikoa egin eta bertan dagokien tratamendua jartzen zaie, bertan osasuna berreskuratzen duten arte. Behin osasun egoera berreskuratu dutela ikustean, La Rochelleko aquariumera eramaten dira bertan, Frantziar Atlantiar kostaldean jaso diren beste dortoka guztiekin batera askatuak izan daitezen. Gurean jasotako dortokak, F letra daramate, zenbaki frantsesekin markatuak izaten dira eta eta ondoren beren habitatean aske uzten dira.

GAKO-HITZAK: Kontserbazioa, benetazko kareta, errekuperazioa, askatzea, markajea

\section{INTRODUCTION}

Caretta caretta (Linneaus, 1758) or loggerhead turtle is the most common turtle species seen in the Bay of Biscay (PenAs-PATIÑO \& PIÑEIRO, 1989). All sea turtles species are in decline, so threatened and listed in the Red List of the IUCN (International Union for the Conservation of Nature). C. caretta is listed as endangered. The main threats that loggerheads can encounter in the Bay of Biscay are accidental entanglement in fishing lines, boat propeller injuries and sickness due to low sea water temperatures for juveniles which get astray and are frequently found floating adrift and stranded on the beaches.

Since its foundation, the Aquarium has received sea turtles that were brought by fishermen or recreation boats that found them adrift in nearby waters or entangled in fishing lines. In fact one of the first detailed studies of a leatherback turtle, caught accidentally in a tuna fishing line in Mutriku (Guipúzcoa) was undertaken at the Aquarium of the Sociedad de Oceanografía de Guipúzcoa by NAVAZ \& GOMEZ DE LLARENA (1951).

In 1996 two Loggerheads were released without tags near San Sebastian coast. Although the number of sea turtles that are recovered at the Aquarium is small, it was decided that it would be essential to tag them before releasing back in the sea. We considered that tagging of this species would help to clarify some doubts about their migratory routes, so it was decided that tags should be obtained. A contact was established with the Aquarium of La Rochelle (France) where they have a programme for Conservation of sea turtles.

\section{MATERIALS AND METHODS}

At arrival, sea turtles were registered. A first macroscopic observation was carried out, they were weighed in kilograms and sized: curved carapace length $(\mathrm{CCL})$ and 
curved carapace width (CCW) in centimetres and accommodated in an independent 450-litre polyester square quarantine tank with temperature control. The diagnosis of specimens was conducted in a veterinarian clinic with $\mathrm{x}$ ray facilities, when necessary a blood sample was taken for its analysis. In the cases where an unknown pathology was present a sample of tissue (skin) was sent to a specialized laboratory (Department of Animal Pathology of the University of Zaragoza). Once sea turtles were diagnosed, appropriate treatment was given to them. The quarantine protocol for the recuperation of loggerheads is shown in Table 1.

\begin{tabular}{|l|}
\hline QUARANTINE CONDITIONS \\
- Isolated polyester square quarantine tanks of 450 litres with $20 \mathrm{~cm}$ of \\
water column so they will be able to breathe air without much effort. \\
\hline - At arrival acclimatizing at ambient sea water temperature. After 24 \\
hours a slow increase of the water temperature is achieved until reaching \\
$22-25^{\circ} \mathrm{C}$ which is the recovery temperature. \\
\hline - Daily water parameters are measured. \\
\hline - Daily vacuning, water change and disinfection of the tank. \\
\hline - Photoperiod following natural solar light. \\
\hline - Feeding is offered twice a day. \\
\hline - Medical treatment is followed. \\
\hline
\end{tabular}

Table 1.- Quarantine protocol for sea turtles $C$. caretta at arrival at the Aquarium of San Sebastián.

Once they recovered, sea water temperature of the tank was lowered down gradually to equalize with the sea water temperature of the next step, which is a larger quarantine tank of 20.000 litres, before transferring them into the main tank of the Aquarium 1.500.000 litres where they are maintained at $18 \pm 1^{\circ} \mathrm{C}$. When sea water temperature is warm (normally month of June) specimens which have recovered satisfactorily at the Aquarium are moved to the Centre d'Études et des Soins des Tortues Marines located at the Aquarium of La Rochelle (Atlantic French coast). Specimens are tagged with a metal (titanium) flipper tag in the front right flipper (Fig. 1), with French nomenclature F and released back to the sea with other specimens recovered in other aquaria of the Atlantic French coast.

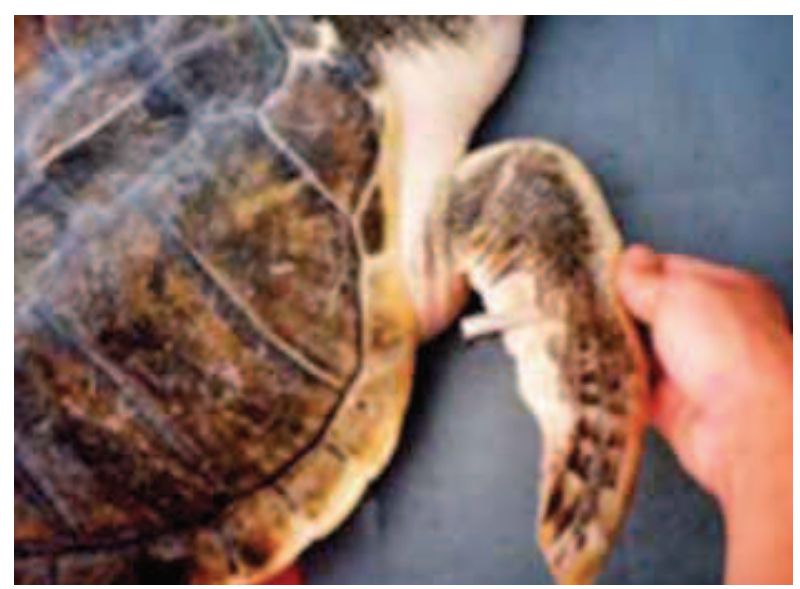

Fig. 1.- Detail of the metal (titanium) flipper tag used for $C$. caretta.

\section{RESULTS}

Figure 2 shows the number of loggerheads recorded at the Aquarium since year 2000; a total of 15 specimens were rescued from floating adrift and stranded on the beaches mainly on the Guipuzcoan coast. Unfortunately one was dead at arrival and two other died after 24 hours. Mean weight was $2.213,6 \pm 1.851,7 \mathrm{~kg}, \mathrm{CCL} 25,57 \pm 5,07 \mathrm{~cm}$ and CCW 23,20 $\pm 4,94 \mathrm{~cm}$.

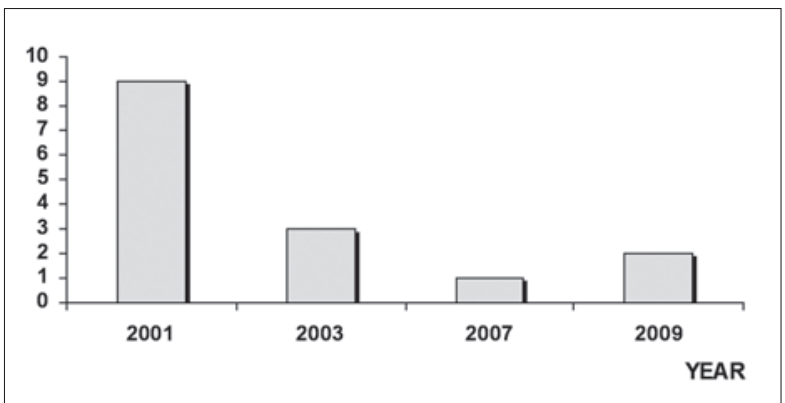

Fig. 2.- Number of specimens of $C$. caretta received at the Aquarium of San Sebastián 2001-2009.

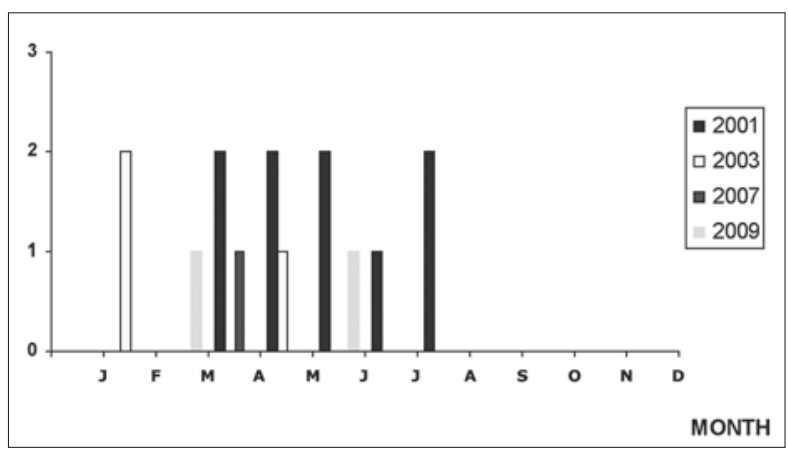

Fig. 3.- Temporal distribution of C. caretta entries at the Aquarium of San Sebastian.

Figure 3 shows the temporal distribution of loggerhead rescues. Apparently, there is not a clear seasonal pattern, it can be observed that winter and spring months could be the most frequent periods for seeing sea turtles, if it is not taken into account an extraordinary year 2001 when most were rescued in spring and summer.

Diagnostics showed that the most common illnesses found were pulmonary infections, hypothermia and dehydration among others; $46 \%$ of specimens presented lung infection (Bronchopneumonia) showing difficulty in breathing and inability to submerge, $33 \%$ skin infection by $\mathrm{C}$ trobacter freundii (Braak 1928) Werkman and Gillen 1932 (Approved Lists 1980) which produced the loss of tissue, 26.6\% eyes and mouth infections produced by Aspergillus sp. and $13,3 \%$ fuel intoxication, due probably to the "Prestige" oil spilling. Table 2 shows the veterinary treatment followed at the quarantine of the Aquarium of San Sebastián to recover sea turtles. Loggerheads were fed with sardines (with viscera), squids, mussels, shrimps with vitamins, at least twice a day until recovery. 
During the month of June, sea turtles are transported to La Rochelle (French Atlantic coast) where they are tagged and released back to the sea. Figures 4 and 5 show the number of loggerheads tagged and released and their biometrics upon arrival to La Rochelle, respectively. At release mean weight was $10.721,25 \pm 4.327,93 \mathrm{~kg}, \mathrm{CCL}$ $26,78 \pm 6,01 \mathrm{~cm}$ and CCW 24,525 $\pm 5,84 \mathrm{~cm}$.

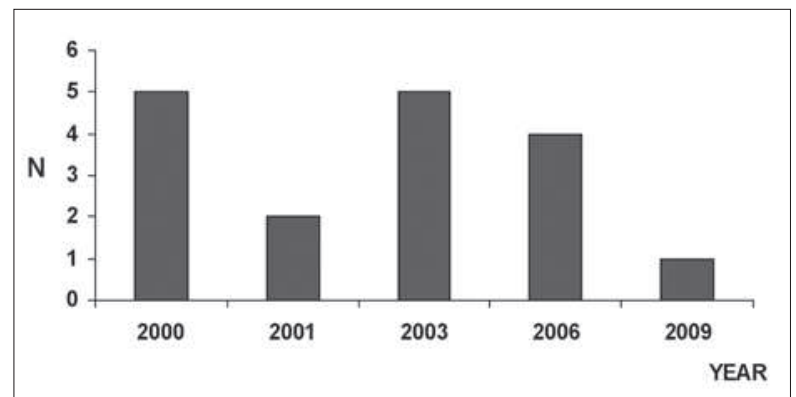

Fig. 4.- Number of $C$. caretta tagged and released at La Rochelle. Note than in year 2000, five sea turtles that were at the Aquarium of whom there is not data of arrival available were released.

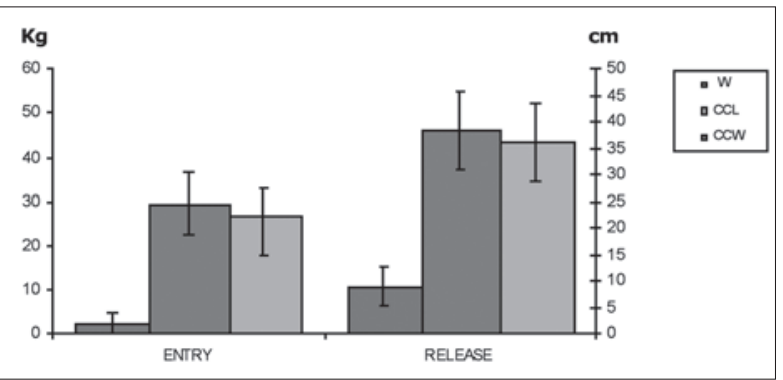

Fig. 5.- Weight in kilograms, curved carapace length (CCL) and curved carapace width $(\mathrm{CCW})$ in centimetres of specimens of $C$. caretta recovered at the Aquarium since year 2001, tagged and released at La Rochelle.

\section{DISCUSSION}

Sea turtle specimens that are brought to the Aquarium are juvenile or subadult loggerheads $(C C L<25,57 \pm 5,07$ $\mathrm{cm}$ ) that wander around in waters of the Bay of Biscay and that can be considered accidentally encountered because they have strayed away from their normal geographic range. Atlantic loggerhead turtles are born in the West Atlantic. After hatching, they disappear to start what is called the "lost year" (Bolten \& BALAzS, 1995) in which their distribution is unknown and are associated with Sargassum communities (Sargassum sp.) adrift. Other studies show that they enter the Gulf Stream current and belong to the pelagic-plantonic communities, which transport them along to the North Atlantic (Bolten et al., 1998).

Sea turtles are not capable of maintaining a constant body temperature. Thus during autumn and winter, mean surface sea water temperature in the Basque coast is $12^{\circ} \mathrm{C}$ $\left(9,2-14,2^{\circ} \mathrm{C}\right.$ ), (unpublished data of the last ten years taken at the Aquarium of San Sebastián) and sea turtles encounter these waters too cold. ScHARTz (1978) found that below $15^{\circ} \mathrm{C}$ adults sea turtles decrease quickly their acti- vities and tend to float allowing the currents to transport them. At temperatures below $10^{\circ} \mathrm{C}$ they stop feeding and it is fatal when they stay for relatively long periods. Thus loggerheads that encounter low water temperatures in the Bay of Biscay stop feeding and as a consequence they are weak against infectious agents. Due to the fact that all species of sea turtles breathe air, they are very sensitive to lung infections, as shown by our results. Juvenile specimens of loggerheads found in our waters will die without the chance to contribute to the reproductive populations if they do not receive help. Sea turtles, if caught on time, respond very well to the treatments, in fact the success of recovery was of $85,7 \%$. Depending on the degree of damage a range from 32 to 92 days is needed. Results show that there is not a clear seasonal pattern for sights of loggerhead in the Basque coast. An extraordinary year was 2001 when 8 specimens were brought to the Aquarium during spring and summer. According to Dugur et al. (2004) this great number was related to a meteorological factor due to the Portugal current.

Although the number of specimens that arrive at our coast is low, San Sebastián Aquarium has joined a programme of conservation of sea turtles coordinated by the Aquarium of La Rochelle (France), which follows the recommendations for conservation of these species in the Northeast Atlantic (FRETEY, 2001). The objective is to recover specimens that are found floating adrift and stranded on the beaches with the aim that they have the chance to reintegrate in the reproductive populations of America or North Africa. Specimens which have recovered satisfactorily in the Aquarium of San Sebastian and other aquaria of the Atlantic French coast are tagged and released offshore La Rochelle when sea water temperature is warm, normally during the month of June, so they have all summer to find their way back to their breeding sites. In the past ten years two tagged loggerheads have been found stranded on the beaches of the north coast of Spain; F 136 dead in September in 2003 in Noja (Cantabria) and F1934 found alive in March 2009 in Guetaria (Basque country). Thus the number of loggerheads that have not succeeded to exit the Bay of Biscay is very small compared with the number of specimens tagged and released, see Dugur et al. (2000, 2001, 2002, 2004, 2005, 2007) for a review.

Conservation programs for this species are very well established in other areas such as the Mediterranean and the Canary islands, but not in the Cantabrian coast of Spain. It is necessary to have a better flow of information between all the regional communities involved and especially between Vizcaya and Guipuzcoa, both on the Basque coast, since we don't know what is really happening at the bottom of the Bay of Biscay because the data that we present here is not complete. A uniform criterion among all the institutions involved in recovering sea turtles, their tagging and release is necessary to really understand and help sea turtles in their journey. The Aquarium of San Sebastian is the only facility in the Basque coast that have the capability of holding sea turtles until they are tagged and released, so it plays an important role in the conservation of sea turtles at the bottom of the Bay of Biscay. 


\section{REFERENCES}

Bolten, A.B., Balazs, G.H. 1995. Biology of the Early Pelagic Stage - The "Lost Year". In: Biology and conservation of sea turtles, revised edition. K. A. Bjorndal (Ed): 575-581. Smithsonian Institution Press, Washington, D.C.

Bolten, A. B., Buorndal, K. A., Martins, H. R., Dellinger, T., BisCOITO, M. J., ENCALADA, S. E., Bowen, B.W. 1998. Transatlantic developmental migrations of loggerheads sea turtles demonstrated by mtDNA sequence analysis. Ecol. Appl. 8(1): 1-7.

Duguy, R., Morinière, P., Meunier, A. 2000. Observations de tortues marines en 1999 (Atlantique et Manche). Ann. Soc. Sci. Nat. Charente-Maritime 8(7): 1025-1034

Duguy, R., Moriniėre, P., Meunier, A. 2001. Observations de tortues marines en 2000 (Atlantique et Manche). Ann. Soc. Sci. Nat. Charente-Maritime 9(1): 17-25.

Duguy, R., Morinière, P., Meunier, A. 2002. Observations de tortues marines en 2001 (Atlantique et Manche). Ann. Soc. Sci. Nat. Charente-Maritime 9(2): 161-172.

Duguy, R., Morinière, P., Meunier, A. 2004. Observations de tortues marines en 2003 (Côtes atlantiques). Ann. Soc. Sci. Nat. Charente-Maritime 9(4): 361-366.
Duguy, R., MORINIÉre, P. MEunier, A. 2005, Observations de tortues marines en 2004 (Côtes atlantiques). Ann. Soc. Sci. Nat. Charente-Maritime 9(5): 461-466.

Duguy, R., Morinière, P., Meunier, A. 2007. Observations de tortues marines en 2006 (Golfe de Gascogne). Ann. Soc. Sci. Nat. Charente-Maritime 9(7): 695-698.

FreteY, J. 2001. Biogeography and Conservation of Marine Turtles of the Atlantic Coast of Africa. CMS Technical Publication 6. UNEP/CMS Secretariat, Bonn.

Navaz, J. M., Gomez de LlerenA, J. 1951. Nota acerca de una tortuga de cuero, "Dermochelys coriacea" (L), capturada en aguas de Guipúzcoa. Soc. Oceanogr. Guipúzcoa 9: 13.

Penas-Patiño, X. M., Piñeiro Seage, A. 1989. Cetáceos, Focas e tartarugas mariñas das costas Ibéricas. Consellería de Pesca, Dirección Xeral de Formación e Promoción Social Pesqueira. Santiago de Compostela.

SCHARTZ, F. J. 1978. Behavioral and tolerance responses to cold water temperatures by three species of sea turtles (Reptilia, Cheloniidae) in North Carolina. Florida Mar. Res. Publ. 33 16-18. 